\title{
ANALIZA PRZYDATNOŚCI SZKOLENIA SPECJALIZACYJNEGO W DZIEDZINIE PIELEGGNIARSTWA OPIEKI PALIATYWNEJ ORAZ WYKORZYSTANIA KWALIFIKACJI SPECJALISTÓW W CELU ZAPEWNIENIA WYSOKIEJ JAKOŚCI OPIEKI PALIATYWNO-HOSPICYJNEJ
}

\author{
ANALYSIS OF THE USEFULNESS OF SPECIALISATION TRAINING IN PALLIATIVE CARE \\ NURSING, AND THE USE OF SPECIALIST QUALIFICATIONS IN ORDER TO ENSURE THE HIGH \\ QUALITY OF PALLIATIVE-HOSPICE CARE
}

\author{
Ewa Kądalska ${ }^{1}$, Halina Zmuda-Trzebiatowska² \\ ${ }^{1}$ Klinika i Poliklinika Geriatrii \\ Narodowy Instytut Geriatrii, Reumatologii i Rehabilitacji im. prof. dr hab. med. Eleonory Reicher w Warszawie \\ ${ }^{2}$ Zakład Pielęgniarstwa Klinicznego \\ Warszawski Uniwersytet Medyczny
}

DOI: https://doi.org/10.20883/pielpol.2017.9

\section{STRESZCZENIE}

Wstęp. Działania mające na celu poprawę dostępności i jakości świadczeń zdrowotnych w obszarze opieki paliatywno-hospicyjnej wymagają wykorzystania specjalistycznych kwalifikacji kadry pielęgniarskiej.

Cel. Analiza przydatności szkolenia specjalizacyjnego w dziedzinie pielęgniarstwa opieki paliatywnej oraz możliwości praktycznego wykorzystania nabytych specjalistycznych kwalifikacji - opinie specjalistów w tej dziedzinie.

Materiał i metody. W badaniu ankietowym udział wzięło 184 specjalistów w dziedzinie pielęgniarstwa opieki paliatywnej, pochodzących z sześciu województw. Do analizy statystycznej wyników badań wykorzystano program SPSS Statistics 22.0.

Wyniki. Większość badanych podkreśliła przydatność szkolenia specjalizacyjnego (93\%), zwłaszcza w zakresie zdobycia doświadczenia zawodowego $(57,1 \%)$, uprawnień do samodzielnego wykonywania określonych świadczeń zdrowotnych (55,9\%). Ukończona specjalizacja wpływa na lepszą jakość pracy (73,9\%), większą fachowość i biegłość w wykonywaniu czynności zawodowych oraz wysoką sprawność działania pielęgniarek (64,1\%). Zapewnia też satysfakcję i prestiż (55\%). Korzyści te częściej dostrzegały specjalistki pracujące w hospicjum domowym $(p=0,03)$. Niektórzy badani podali, że wykonują specjalistyczne świadczenia wymagające dodatkowych uprawnień, związane głównie z udziałem w obserwacji i terapii bólu przewlekłego oraz oceną jakości życia chorego.

Wnioski. Według specjalistów w dziedzinie pielęgniarstwa opieki paliatywnej podniesienie kwalifikacji skutkuje satysfakcją osobistą i uznaniem społecznym. Niektórzy respondenci podkreślali poprawę efektywności opieki nad chorymi. Największą samodzielnością zawodową cechują się pielęgniarki w hospicjum domowym i stacjonarnym, ale wysokie kwalifikacje tej kadry nie są w petni wykorzystywane.

SŁOWA KLUCZOWE: specjaliści, pielęgniarstwo opieki paliatywnej.

\begin{abstract}
Introduction. Activities aimed at better availability and quality of health services concerning palliative and hospice care require the use of specialist qualifications of the nursing personnel.

Aim. Analysis of the significance of a specialised palliative nursing care training programme and the possibilities of application of acquired qualifications in nursing practice, as seen by respective professionals.

Material and methods. The survey covered 184 palliative care professionals from 6 voivodeships. Statistical analysis of the research results was performed with SPSS Statistics 22.0. software. Results. A majority of the surveyed stressed the usefulness of the specialised palliative nursing care training programme (93\%), also in relation to gaining professional experience $(57.1 \%)$ and obtaining qualifications needed to provide certain healthcare services independently $(55.9 \%)$. The training programme enhanced the quality of work $(73.9 \%)$, raised expertise and competence within professional duties, and improved the efficiency of care provided by nurses $(64.1 \%)$, while being gratifying and prestigious $(55 \%)$. The benefits were principally realised by health care professionals working in home hospices $(p=0.03)$. Some of the surveyed claimed they provided specialised healthcare services requiring additional qualifications, mainly due to chronic pain management and monitoring and to assessing the quality of patients' life.

Conclusions. According to palliative nursing care specialists, improving qualifications primarily results in gaining self-satisfaction and social recognition. Only few of the surveyed mentioned the improved efficiency in the patient care. The nurses working in home and inpatient hospices are the most independent and self-reliant, although high qualifications of staff are not fully utilised.
\end{abstract}

KEYWORDS: specialists, palliative care nursing. 


\section{Wprowadzenie}

Świadczenia opieki paliatywnej i hospicyjnej obejmują wszechstronną, całościową opiekę i leczenie objawowe świadczeniobiorców chorujących na choroby nieuleczalne, niepoddające się leczeniu przyczynowemu, postępujące i ograniczające życie. Opieka ta jest zatem ukierunkowana na poprawę jakości życia chorych, poprzez zapobieganie bólowi i innym objawom somatycznym, a także łagodzenie cierpień psychicznych, duchowych i socjalnych.

Rozporządzenie Ministra Zdrowia z dnia 29 października 2013 r. w sprawie świadczeń gwarantowanych z zakresu opieki paliatywnej hospicyjnej (Dz.U. z 2013 r. poz. 1347) określa rodzaj i miejsca świadczenia tych usług. Świadczenia gwarantowane przysługujące chorym na choroby nowotworowe i nienowotworowe mogą być realizowane $w$ warunkach: ambulatoryjnych - w poradni medycyny paliatywnej, domowych - w hospicjum domowym dla dorosłych lub dla dzieci, oraz w warunkach stacjonarnych - w hospicjum stacjonarnym lub w oddziale medycyny paliatywnej. W rozporządzeniu tym określono warunki realizacji świadczeń, przy czym wobec pielęgniarki sprecyzowano, że jest to przede wszystkim ukończenie specjalizacji lub kursu kwalifikacyjnego w dziedzinie pielęgniarstwa opieki paliatywnej, chociaż dopuszcza się również inne kwalifikacje podyplomowe [1].

Specjalizacja jest formą doskonalenia zawodowego pielęgniarek, której celem - zgodnie z Ustawą z dnia 15 lipca 2011 r. o zawodach pielęgniarki i położnej (Dz.U. Nr 174, poz. 1039 z późn. zm.) - jest uzyskanie przez pielęgniarkę lub położną specjalistycznej wiedzy i umiejętności w określonej dziedzinie pielęgniarstwa lub dziedzinie mającej zastosowanie w ochronie zdrowia, a potwierdzeniem tych kompetencji jest uzyskanie tytułu specjalisty w danej dziedzinie pielęgniarstwa [2]. Według danych Centrum Kształcenia Podyplomowego Pielęgniarek i Położnych na dzień 31 maja 2015 r. w kraju zarejestrowano 729 specjalistów w dziedzinie pielęgniarstwa opieki paliatywnej.

W świetle Rozporządzenia Ministra Zdrowia z dnia 7 listopada 2007 r. w sprawie rodzaju i zakresu świadczeń zapobiegawczych, diagnostycznych, leczniczych i rehabilitacyjnych udzielanych przez pielęgniarkę albo położną samodzielnie bez zlecenia lekarskiego (Dz.U. $\mathrm{Nr} 210$, poz. 1540) pielęgniarka legitymująca się tytułem specjalisty ma możliwości skorzystania z uprawnień wykonywania niektórych świadczeń (w razie nieobecności lekarza), a następnie niezwłocznego poinformowania lekarza prowadzącego o udzielonym świadczeniu. Do świadczeń szczególnie powierzonych specjalistce pielęgniarstwa opieki paliatywnej należą te związane głównie z udziałem w obserwacji i terapii bólu przewlekłego, oceną jakości życia chorego, prowadzeniem psychoterapii podstawowej i niektórych form rehabilitacji [3].

W pracy podjęto analize, dokonanej przez specjalistów pielęgniarstwa opieki paliatywnej, oceny przydatności szkolenia specjalizacyjnego do samodzielnej realizacji świadczeń, a także korzystania z niektórych uprawnień specjalistów do realizacji świadczeń wykonywanych samodzielnie.

\section{Materiał i metody}

W badaniu ankietowym wzięło udział 184 specjalistów w dziedzinie pielęgniarstwa opieki paliatywnej, pracujących w hospicjach domowych, stacjonarnych oraz poradniach i szpitalnych oddziałach paliatywnych. Byli to specjaliści z sześciu województw: pomorskiego, mazowieckiego, lubelskiego, podkarpackiego, śląskiego i dolnośląskiego. Badania przeprowadzono w okresie od grudnia 2014 r. do kwietnia 2015 r. W celu zebrania danych posłużono się autorskim kwestionariuszem ankiety, którego weryfikacje przeprowadzono w 20-osobowej grupie pilotażowej pielęgniarek specjalistek. Do analizy statystycznej wyników badań wykorzystano program SPSS Statistics 22.0. W celu porównania rozkładów zmiennych nominalnych pochodzących z dwu lub więcej grup zastosowano test chi-kwadrat Pearsona. Siłę związku dwóch zmiennych przedziałowych oceniano przy zastosowaniu współczynnika korelacji Pearsona.

\section{Wyniki}

Wśród specjalistów w dziedzinie pielęgniarstwa opieki paliatywnej objętych badaniem zdecydowanie przeważały kobiety (K: $\mathrm{N}=181 ; 98,4 \%, \mathrm{M}: \mathrm{N}=3 ; 1,6 \%)$.

Badani byli zróżnicowani pod względem wieku, przy czym najliczniejszą grupę stanowiły osoby w przedziale wiekowym $40-50$ lat $(\mathrm{N}=93 ; 50,5 \%)$ oraz $\mathrm{w}$ wieku $30-$ 40 lat $(N=48 ; 26,1 \%)$, a nieco mniej liczną - powyżej 50 lat $(N=35,19 \%)$ i pomiędzy 25. a 30. rokiem życia $(\mathrm{N}=6 ; 3,4 \%)$. Najwięcej respondentów legitymowało się wykształceniem średnim ( $N=73 ; 39,7 \%)$, następnie wyższym zawodowym ( $\mathrm{N}=62 ; 33,7 \%)$ oraz wyższym magisterskim (47; 25,5\%).

Badana grupa specjalistów w dziedzinie pielęgniarstwa opieki paliatywnej wskazywała różne miejsca pracy (Tabela 1). 
Tabela 1. Respondenci według miejsca pracy

Table 1. The surveyed according to the workplace and professional experience

\begin{tabular}{|c|c|c|}
\hline Miejsce pracy/Workplace & $\mathrm{N}$ & $\begin{array}{c}\text { Procent/ } \\
\text { Percentage }\end{array}$ \\
\hline Poradnia medycyny paliatywnej/Palliative clinic & 3 & 1,6 \\
\hline Hospicjum domowe/Home hospice & 54 & 29,3 \\
\hline Hospicjum stacjonarne/Inpatient hospice & 25 & 13,6 \\
\hline Hospicjum dla dzieci/Children's hospice & 13 & 7,1 \\
\hline Oddział medycyny paliatywnej/Palliative hospital ward & 18 & 9,8 \\
\hline $\begin{array}{l}\text { Inne miejsca (np. szpitalne oddziały onkologiczne, zakłady } \\
\text { opieki długoterminowej, zakłady podstawowej opieki } \\
\text { zdrowotnej)/Other (e.g. oncology wards, long-term health } \\
\text { centres, health service establishments) }\end{array}$ & 53 & 28,8 \\
\hline Brak odpowiedzi/No response & 18 & 9,8 \\
\hline Razem/Total & 184 & 100 \\
\hline
\end{tabular}

Źródło: opracowanie własne

Source: author's own analysis

Najwięcej osób podawało jako miejsce pracy hospicjum domowe $(\mathrm{N}=54 ; 29,3 \%)$. Inne miejsca pracy często wymieniane przez badanych ( $N=53 ; 28,8 \%$ ) to: oddziały onkologiczne w szpitalach, stacjonarne zakłady opieki długoterminowej, zakłady podstawowej opieki zdrowotnej (pielęgniarki środowiskowe-rodzinne). W hospicjach stacjonarnych pracowało $13,6 \%$ respondentów $(N=25)$, a w poradniach medycyny paliatywnej $-1,6 \%(\mathrm{~N}=3)$. Średni staż pracy zawodowej wynosił w badanej grupie 22 lata, a staż w opiece paliatywno-hospicyjnej - 6,5 roku.

Wskazując na własne oczekiwania w związku z przystąpieniem do specjalizacji, badani kierowali się przeważnie względami praktycznymi. W tabeli 2 zestawiono odpowiedzi udzielone na to pytanie.

Tabela 2. Własne oczekiwania w związku z przystąpieniem do specjalizacji w dziedzinie pielęgniarstwa opieki paliatywnej

Table 2. Expectations about the specialised palliative nursing care training programme

\begin{tabular}{|c|c|c|c|c|c|}
\hline $\begin{array}{l}\text { Odpowiedzi*/ } \\
\text { Responses } \\
\text { N }=184\end{array}$ & $\begin{array}{c}\text { Średnia } \\
\text { ranga/ } \\
\text { Average } \\
\text { rank }\end{array}$ & $\begin{array}{l}\text { Łącznie/ } \\
\text { Procent/ } \\
\text { Total/ } \\
\text { Percen- } \\
\text { tage }\end{array}$ & $\begin{array}{l}\text { Ranga } \\
1 / \mathrm{N} / \\
\text { Procent/ } \\
\text { Rank } 1 / \mathrm{N} / \\
\text { Percen- } \\
\text { tage }\end{array}$ & $\begin{array}{l}\text { Ranga } \\
\text { 2/N/ } \\
\text { Procent/ } \\
\text { // Rank 2/N/ } \\
\text { Percen- } \\
\text { tage }\end{array}$ & $\begin{array}{l}\text { Ranga } 3 / \mathrm{N} / \\
\text { Procent/ } \\
\text { Rank } 3 / \mathrm{N} / \\
\text { Percentage }\end{array}$ \\
\hline $\begin{array}{l}\text { Zdobycie doświad- } \\
\text { czenia zawodowego/ } \\
\text { Gaining professional } \\
\text { qualifications }\end{array}$ & 1,5 & $105 / 57,1$ & $67 / 36,4$ & $19 / 10,3$ & $19 / 10,3$ \\
\hline $\begin{array}{l}\text { Uzyskanie uprawnień do } \\
\text { samodzielnego wyko- } \\
\text { nywania określonych } \\
\text { świadczeń zdrowotnych/ } \\
\text { Obtaining qualifications } \\
\text { needed to provide cer- } \\
\text { tain healthcare services } \\
\text { independently }\end{array}$ & 1,6 & $103 / 55,9$ & $54 / 29,4$ & $33 / 17,9$ & $16 / 8,7$ \\
\hline
\end{tabular}

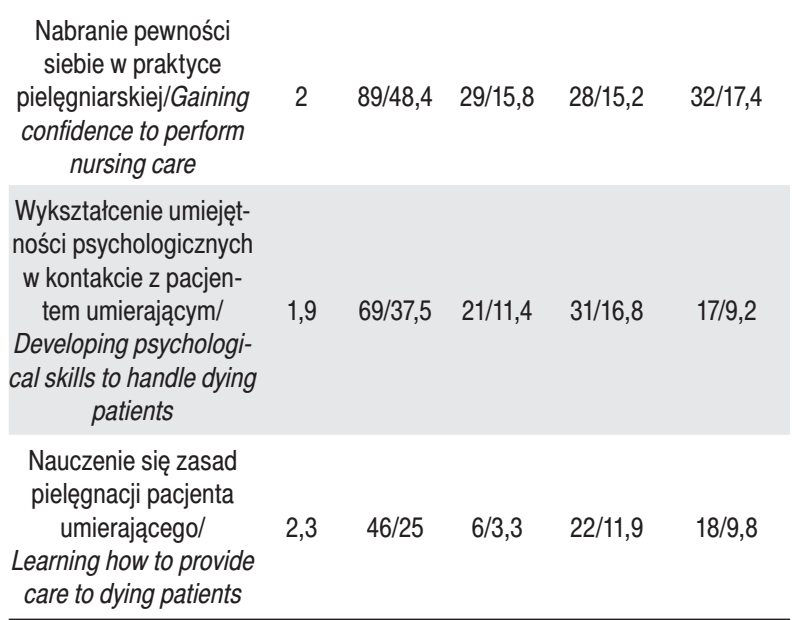

*Odpowiedzi należało uszeregować w kolejności od 1 do 3 , przypisując poszczególnym stwierdzeniom odpowiednie rangi, przy czym cyfra 1 oznaczała najważniejszą odpowiedź

*The responses had to be ranked from 1 to 3 with 1 as the highest rank

Źródło: opracowanie własne

Source: author's own analysis

Ankietowani, rozpoczynając szkolenie specjalizacyjne, najbardziej oczekiwali zdobycia doświadczenia zawodowego (ranga $1 \mathrm{~N}=67 ; 36,4 \%$; najwyższa średnia ranga - 1,5), uzyskania uprawnień do samodzielnego wykonywania określonych świadczeń zdrowotnych (ranga $1 \mathrm{~N}=54 ; 29,4 \%$ ), a także nabrania pewności siebie w praktyce pielęgniarskiej (ranga $1 \mathrm{~N}=29 ; 15,8 \%$ ). W dalszej kolejności podawano chęć wykształcenia umiejętności psychologicznych w kontakcie z pacjentem umierającym (ranga $2 \mathrm{~N}=31 ; 16,8 \%$ ). Zdaniem 172 respondentów $(93,5 \%)$ odbyta specjalizacja była potrzebna. Tylko 7 osób $(3,8 \%)$ uznało, że nie była ona konieczna, ale dobrze, że się odbyła. Według $73,4 \%$ badanych $(\mathrm{N}=135)$ kurs specjalizacyjny spełnił ich oczekiwania, czego nie mogło potwierdzić $17,9 \%$ badanych $(\mathrm{N}=33)$. Jednocześnie według większości liczba godzin zajęć realizowanych podczas szkolenia specjalizacyjnego była wystarczająca ( $\mathrm{N}=147 ; 79,9 \%$ ).

Odpowiadając na pytanie otwarte, ankietowani podali treści kształcenia, o które w przyszłości warto poszerzyć szkolenie specjalizacyjne, zarówno w aspekcie teoretycznym, jak i praktycznym; wskazali przede wszystkim na zagadnienia dotyczące: psychoonkologii oraz prowadzenia rozmowy z rodziną i umierającym $(N=32 ; 17,3 \%)$, onkologii dziecięcej $(N=26 ; 14,1 \%)$ i opieki paliatywno-hospicyjnej nad dziećmi ( $N=14 ; 7,6 \%)$.

Kolejne pytania dotyczyły dostrzeganych przez respondentów korzyści z ukończenia specjalizacji i ich wpływu na wykonywanie pracy oraz czynności zawodowych.

Zdaniem większości badanych ukończenie specjalizacji przynosi prestiż $(N=102 ; 55,4 \%)$ oraz szacunek 
współpracowników ( $\mathrm{N}=32 ; 17,4 \%$ ). Według 31 ankietowanych $(16,8 \%)$ ukończenie szkolenia specjalizacyjnego niczego nie zmieniło. Dla 17 respondentów był to wymóg formalny związany z utrzymaniem miejsca pracy $(9,2 \%)$, a dla 15 - możliwość podwyżki $(8,1 \%)$. Na prestiż jako korzyść związaną z ukończeniem specjalizacji wskazywały głównie osoby w wieku poniżej 40 lat ( $\mathrm{N}=32 ; 59,3 \%$ ) oraz powyżej 50 lat ( $\mathrm{N}=21 ; 56,8 \%$ ), legitymujące się wykształceniem wyższym zawodowym ( $N=34 ; 54,8 \%$ ), a także magisterskim ( $N=30 ; 61,2 \%$ ), ze stażem pracy w zawodzie wynoszącym 20 lat i mniej ( $N=56 ; 58,3 \%$ ). Według ogółu uczestników badania ukończenie specjalizacji bezpośrednio wpływa na realizowane czynności zawodowe i aktywność zawodową, głównie poprzez lepszą jakość własnej pracy ( $N=136$; $73,9 \%)$, większą fachowość, biegłość w wykonywaniu czynności, wysoką sprawność ( $N=118 ; 64,1 \%)$ i szybkość podejmowania decyzji ( $N=79 ; 42,9 \%)$. Ponadto specjaliści angażują się w szkolenie/nauczanie innych pielęgniarek, a także opiekunów i wolontariuszy (Tabela 3).

Tabela 3. Wpływ ukończenia specjalizacji w dziedzinie pielegniarstwa opieki paliatywnej na bezpośrednie działania i aktywność zawodową specjalistów Table 3. The effects of completing the palliative nursing care specialisation on direct actions and professional life of the professionals

\begin{tabular}{|c|c|c|}
\hline Odpowiedzi*/Responses ${ }^{*}$ & $\mathrm{~N}$ & $\begin{array}{l}\text { Procent/ } \\
\text { Percentage }\end{array}$ \\
\hline $\begin{array}{c}\text { Fachowość, biegłość w wykonywaniu czynności, wysoka } \\
\text { sprawność/Expertise and competence within professional } \\
\text { duties, high efficiency }\end{array}$ & 118 & 64,1 \\
\hline Lepsza jakość własnej pracy/Enhanced quality of own work & 136 & 73,9 \\
\hline Szybkość podejmowania decyzji/Fast decision making & 79 & 42,9 \\
\hline $\begin{array}{c}\text { Szkolenie/nauczanie innych (pielęgniarek, opiekunów, } \\
\text { wolontariuszy)/Training/educating others (nurses, carers, } \\
\text { volunteers) }\end{array}$ & 30 & 16,3 \\
\hline $\begin{array}{l}\text { Przewodzenie w zespole pielegniarskich, koordynacja } \\
\text { pracy/Leading nursing teams, managing works }\end{array}$ & 22 & 11,9 \\
\hline $\begin{array}{l}\text { Opracowywanie standardów i procedur postępowania } \\
\text { pielęgniarskiego/Defining standards and establishing } \\
\text { procedures for nurses }\end{array}$ & 18 & 9,8 \\
\hline
\end{tabular}

*Odpowiedzi nie sumują się do 184 ze względu na możliwość udzielenia więcej niż jednej odpowiedzi na to pytanie

*The total is more than 184 responses due to the multiple aspect of the question

Źródło: opracowanie własne

Source: author's own analysis

Wyboru „fachowość, biegłość w wykonywaniu czynności, wysoka sprawność" częściej niż inni uczestnicy badania dokonywały osoby $\mathrm{w}$ wieku $40-50$ lat $(\mathrm{N}=$ $66 ; 71 \%)$ i powyżej 50 lat ( $N=23 ; 62,2 \%)$, z wykształceniem wyższym zawodowym ( $N=43 ; 69,4 \%$ ), pielęgniarki specjalistki pracujące w hospicjum domowym ( $N=41 ; 75,9 \%$, różnica istotna statystycznie $p=0,03$, a także osoby ze stażem pracy powyżej 21 lat $(\mathrm{N}=60$; 69\%). Lepszą jakość pracy własnej częściej wskazywa- ły osoby w wieku poniżej 40 lat ( $\mathrm{N}=42 ; 77,8 \%)$ oraz w przedziale wiekowym 40-50 lat ( $N=70 ; 75,3 \%)$, z wykształceniem wyższym zawodowym ( $\mathrm{N}=51$; $82,3 \%$, ze stażem pracy wynoszącym 20 lat lub mniej ( $\mathrm{N}=72 ; 75 \%$ ) oraz ze stażem w opiece paliatywnej 7 lat i więcej ( $N=58 ; 78,4 \%)$.

W Rozporządzeniu Ministra Zdrowia z dnia 7 listopada 2007 r. w sprawie rodzaju i zakresu świadczeń zapobiegawczych, diagnostycznych, leczniczych i rehabilitacyjnych udzielanych przez pielęgniarkę albo położną samodzielnie bez zlecenia lekarskiego zamieszczono wykaz świadczeń przypisanych specjaliście $\mathrm{w}$ dziedzinie pielęgniarstwa opieki paliatywnej. W badaniu zapytano, czy respondenci korzystają z tego typu uprawnień. Odpowiedzi zebrano w tabelach 4 i 5, wyodrębniając świadczenia o charakterze ogólnym i te bardziej specyficzne dla dziedziny opieki paliatywnej, a następnie utworzono zestawienia według liczebności poszczególnych podgrup, pod względem wykształcenia oraz miejsca i stażu pracy.

Tabela 4. Wykorzystanie uprawnień do samodzielnego udzielania niektórych świadczeń przez specjalistów w dziedzinie pielęgniarstwa opieki paliatywnej - świadczenia ogólne

Table 4. Using qualifications to provide certain healthcare services independently by palliative nursing care professionals - general care

\begin{tabular}{|c|c|c|c|c|c|}
\hline \multirow[b]{2}{*}{$\begin{array}{l}\text { Lp./ } \\
\text { Item } \\
\text { no. }\end{array}$} & \multirow[b]{2}{*}{$\begin{array}{l}\text { Nazwa świadczenia/ } \\
\text { Name of service }\end{array}$} & \multicolumn{4}{|c|}{ Odpowiedzi/Responses } \\
\hline & & $\begin{array}{l}\text { Korzystam } \\
\text { z tych } \\
\text { upraw- } \\
\text { nień/l use } \\
\text { qualifica- } \\
\text { tions }\end{array}$ & $\begin{array}{l}\text { Będę } \\
\text { korzystać } \\
\text { z tych } \\
\text { upraw- } \\
\text { nień/ } \\
\text { I will use } \\
\text { qualifica- } \\
\text { tions }\end{array}$ & $\begin{array}{l}\text { Nie ko- } \\
\text { rzystam } \\
\text { z tych } \\
\text { uprawnień/ } \\
\text { I do } \\
\text { not use } \\
\text { qualifica- } \\
\text { tions }\end{array}$ & $\begin{array}{l}\text { Brak odpo- } \\
\text { wiedzi/ } \\
\text { No respon- } \\
\text { se }\end{array}$ \\
\hline 1. & $\begin{array}{l}\text { Wykonywanie badania } \\
\text { fizykalnego/Performing } \\
\text { physical examination }\end{array}$ & $\begin{array}{c}26 \\
14,1 \%\end{array}$ & $\begin{array}{c}3 \\
1,6 \%\end{array}$ & $\begin{array}{c}6 \\
3,3 \%\end{array}$ & $\begin{array}{c}149 \\
80,9 \%\end{array}$ \\
\hline 2. & $\begin{array}{l}\text { Kierowanie na badania } \\
\text { diagnostyczne lub pobiera- } \\
\text { nie materiałów do badan/ } \\
\text { Referring for diagnostic } \\
\text { tests or taking samples to } \\
\text { examine }\end{array}$ & $\begin{array}{c}12 \\
6,5 \%\end{array}$ & $\begin{array}{c}8 \\
4,4 \%\end{array}$ & $\begin{array}{c}13 \\
7,1 \%\end{array}$ & $\begin{array}{c}151 \\
82,1 \%\end{array}$ \\
\hline 3. & $\begin{array}{l}\text { Ocena stanu świadomości } \\
\text { chorego z wykorzystaniem } \\
\text { metod i klasyfikacji/As- } \\
\text { sessing patients' state of } \\
\text { consciousness with the use } \\
\text { of specified methods and } \\
\text { classification }\end{array}$ & $\begin{array}{c}26 \\
14,1 \%\end{array}$ & $\begin{array}{c}2 \\
1,09 \%\end{array}$ & $\begin{array}{c}4 \\
2,2 \%\end{array}$ & $\begin{array}{c}149 \\
80,9 \%\end{array}$ \\
\hline 4. & $\begin{array}{c}\text { Tlenoterapia/Oxygen } \\
\text { therapy }\end{array}$ & $\begin{array}{c}94 \\
51,1 \%\end{array}$ & $\begin{array}{c}29 \\
15,8 \%\end{array}$ & $\begin{array}{c}10 \\
5,4 \%\end{array}$ & $\begin{array}{c}51 \\
27,7 \%\end{array}$ \\
\hline 5. & $\begin{array}{l}\text { Dobór sposobów opatry- } \\
\text { wania ran i odleżyn (wymóg } \\
\text { ukończenia kurs specjalisty- } \\
\text { cznego)/Selecting methods } \\
\text { of dressing wounds and } \\
\text { treating bedsores (special- } \\
\text { ised training required) }\end{array}$ & $\begin{array}{c}126 \\
68,5 \%\end{array}$ & $\begin{array}{c}12 \\
6,5 \%\end{array}$ & $\begin{array}{c}8 \\
4,3 \%\end{array}$ & $\begin{array}{c}39 \\
21,2 \%\end{array}$ \\
\hline
\end{tabular}

Źródło: opracowanie własne

Source: author's own analysis 
Wśród świadczeń ogólnych wymagających ukończenia specjalizacji najczęściej realizowanym była tlenoterapia ( $\mathrm{N}=94 ; 68,5 \%$ ). Z uprawnienia tego korzystały przeważnie osoby z wykształceniem wyższym magisterskim ( $N=32 ; 65,3 \% ; p=0,029$ ) oraz pracujące w hospicjum domowym ( $N=33 ; 61,1 \% ; p=0,052)$. Znacznie rzadziej dokonywano oceny stanu świadomości chorego z wykorzystaniem metod i klasyfikacji ( $\mathrm{N}=26 ; 14,1 \%)$ oraz wykonywano badanie fizykalne $(\mathrm{N}=26 ; 14,1 \%)$.

Oprócz wymienionych świadczeń zdrowotnych, przy których określono wymóg posiadania specjalizacji, w kwestionariuszu zamieszczono dodatkowe pytania dotyczące samodzielnego wykonywania czynności wymagających ukończenia kursu specjalistycznego dobór sposobów opatrywania ran i odleżyn. Z przeprowadzonych badań wynika, że z tego uprawnienia korzystało najwięcej osób - 126 (68,5\%). Były to przeważnie specjalistki z wykształceniem wyższym magisterskim $(\mathrm{N}=39 ; 79,6 \% ; \mathrm{p}=0,003)$ i wyższym zawodowym (48; 77,4\%; $p=0,004)$, pracujące $w$ hospicjum domowym ( $N=45 ; 83,3 \%$; $p=0,014$ ) oraz w hospicjum stacjonarnym $(\mathrm{N}=24 ; 96 \% ; \mathrm{p}=0,017)$. W tabeli 5 zestawiono odpowiedzi dotyczące realizacji świadczeń specjalistycznych w zakresie pielęgniarstwa opieki paliatywnej.

Tabela 5. Wykorzystanie uprawnień do samodzielnego udzielania niektórych świadczeń przez specjalistów w dziedzinie pielęgniarstwa opieki paliatywnej - świadczenia specjalistyczne

Table 5. Using qualifications to provide certain healthcare services independently by palliative nursing care professionals - care

\begin{tabular}{|c|c|c|c|c|c|}
\hline \multirow[b]{2}{*}{$\begin{array}{l}\text { Lp./ } \\
\text { Item } \\
\text { no. }\end{array}$} & \multirow[b]{2}{*}{$\begin{array}{l}\text { Nazwa świadczenia/ } \\
\text { Name of service }\end{array}$} & \multicolumn{4}{|c|}{ Odpowiedzi/Responses } \\
\hline & & $\begin{array}{c}\text { Korzystam } \\
\text { z tych } \\
\text { uprawnie/ } \\
\text { / use } \\
\text { qualifica- } \\
\text { tions }\end{array}$ & $\begin{array}{l}\text { Będe } \\
\text { korzystać } \\
\text { z tych } \\
\text { uprawnień/ } \\
\text { I will use } \\
\text { qualifica- } \\
\text { tions }\end{array}$ & $\begin{array}{l}\text { Nie korzy- } \\
\text { stam } \\
\text { z tych } \\
\text { uprawnień/ } \\
\text { I do } \\
\text { not use } \\
\text { qualifica- } \\
\text { tions }\end{array}$ & $\begin{array}{l}\text { Brak } \\
\text { odpowie- } \\
\text { dzi/ } \\
\text { No } \\
\text { response }\end{array}$ \\
\hline 1. & $\begin{array}{l}\text { Ocena i monitorowanie bólu } \\
\text { oraz innych objawów u prze- } \\
\text { wlekle chorego oraz ocena } \\
\text { wydolności fizycznej chorego/ } \\
\text { Assessing and monitoring pain } \\
\text { and other symptoms in chroni- } \\
\text { cally ill patients, assessing } \\
\text { patients' physical capacity }\end{array}$ & $\begin{array}{c}95 \\
51,6 \%\end{array}$ & $\begin{array}{c}27 \\
19,7 \%\end{array}$ & $\begin{array}{c}12 \\
6,5 \%\end{array}$ & $\begin{array}{c}40 \\
21,7 \%\end{array}$ \\
\hline 2. & $\begin{array}{l}\text { Ocena jakości życia chorego/ } \\
\text { Assessing the quality of pa- } \\
\text { tients' life }\end{array}$ & $\begin{array}{c}92 \\
50 \%\end{array}$ & $\begin{array}{c}26 \\
14,1 \%\end{array}$ & $\begin{array}{c}16 \\
8,7 \%\end{array}$ & $\begin{array}{c}50 \\
27,2 \%\end{array}$ \\
\hline 3. & $\begin{array}{l}\text { Doraźna modyfikacja dawki } \\
\text { leczniczej leku przeciw- } \\
\text { bólowego i leków stosowanych } \\
\text { w celu łagodzenia innych } \\
\text { dokuczliwych objawów } \\
\text { (duszność, nudności, wymioty, } \\
\text { lęk, delirium)/Temporary dose } \\
\text { adjustments of painkillers and } \\
\text { other medicine which mitigates } \\
\text { distressing symptoms (dysp- } \\
\text { nea, nausea, vomiting, anxiety, } \\
\text { delirium) }\end{array}$ & $\begin{array}{c}89 \\
48,4 \%\end{array}$ & $\begin{array}{c}28 \\
15,2 \%\end{array}$ & $\begin{array}{c}18 \\
9,8 \%\end{array}$ & $\begin{array}{c}50 \\
27,2 \%\end{array}$ \\
\hline
\end{tabular}

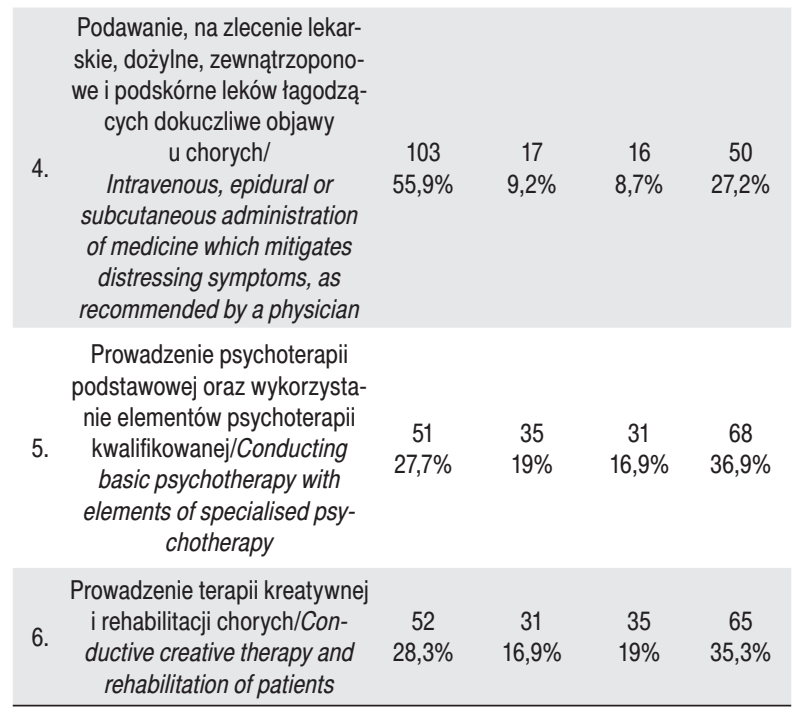

Źródło: opracowanie własne

Source: author's own analysis

Analiza wyników badania wykazała, że ze specjalistycznych świadczeń samodzielnych korzystały przeważnie pielęgniarki ze stażem pracy w opiece paliatywno-hospicyjnej powyżej 7 lat. Realizowane czynności dotyczyły głównie oceny i monitorowania bólu, innych objawów u przewlekle chorego oraz oceny wydolności fizycznej chorego ( $N=49 ; 66,2 \% ; p=0,001)$, doraźnej modyfikacji dawki leczniczej leku przeciwbólowego i leków stosowanych w celu łagodzenia innych dokuczliwych objawów ( $N=49,66,2 \% ; p=0,013$ ), a także podawania na zlecenie lekarskie, dożylnego, zewnątrzoponowego i podskórnego leków łagodzących dokuczliwe objawy u chorych $(\mathrm{N}=53 ; 71,6 \% ; \mathrm{p}=0,001)$.

Osoby z wykształceniem wyższym magisterskim wskazywały przeważnie na dokonywaną ocene jakości życia chorego ( $N=35 ; 71,4 \% ; p<0,005)$, doraźną modyfikację dawki leczniczej leku przeciwbólowego i leków stosowanych w celu łagodzenia innych dokuczliwych objawów ( $N=33 ; 67,3 \%$; $p=0,005$ ), prowadzenie psychoterapii podstawowej oraz wykorzystanie elementów psychoterapii kwalifikowanej ( $N=21 ; 42,9 \% ; p=0,008)$, a także prowadzenie terapii kreatywnej i rehabilitacji chorych ( $N=22 ; 44,9 \% ; p=0,007)$.

Pielęgniarki specjalistki pracujące w hospicjum domowym najczęściej samodzielnie prowadziły ocenę i monitorowanie bólu, innych objawów u przewlekle chorego oraz ocenę wydolności fizycznej chorego $(\mathrm{N}=36 ; 66,7 \% ; \mathrm{p}=0,03)$, ocenę jakości życia chorego $(\mathrm{N}=41 ; 75,9 \% ; \mathrm{p}<0,005)$, a także doraźnie modyfikowały dawkę leczniczą leku przeciwbólowego i leków stosowanych w celu łagodzenia innych dokuczliwych objawów ( $N=35 ; 64,8 \% ; p=0,003$ ). Grupę tę wyróżniało też częstsze korzystanie z uprawnienia do podawania dożylnego, zewnątrzoponowego i podskórnego 
leków przeciwbólowych i innych leków łagodzących dokuczliwe objawy u chorych ( $N=36 ; 66,7 \% ; p=0,05)$, a także prowadzenie psychoterapii podstawowej oraz wykorzystanie elementów psychoterapii kwalifikowanej ( $N=28 ; 51,9 \% ; p<0,005)$. Wśród osób, których miejscem pracy było hospicjum stacjonarne, przeważnie dokonywano oceny i monitorowania bólu, innych objawów u przewlekle chorego oraz oceny wydolności fizycznej chorego ( $\mathrm{N}=20 ; 80 \% ; \mathrm{p}=0,02$ ), a także doraźnie modyfikowano dawkę leczniczą leku przeciwbólowego i leków stosowanych w celu łagodzenia innych dokuczliwych objawów ( $\mathrm{N}=20 ; 80 \% ; \mathrm{p}=0,008$ ) oraz prowadzono ocenę jakości życia chorych ( $N=41 ; 75,9 \%$; $\mathrm{p}<0,005)$.

Respondenci sygnalizowali jednocześnie, że nie korzystają z niektórych uprawnień ze względu na brak wystarczającej wiedzy lub pewności siebie, realizację tych świadczeń przez innych specjalistów, np. lekarzy, psychologów, albo też opór lub brak zainteresowania pracodawcy w zakresie formalnego rozszerzenia uprawnień pielęgniarek.

Wśród pytań podsumowujących znalazło się pytanie otwarte o to, co w praktyce daje specjaliście w dziedzinie pielęgniarstwa opieki paliatywnej ukończenie szkolenia specjalizacyjnego. Większość odpowiadających wskazała tu na podniesienie kwalifikacji ( $N=56$; 30,4\%), poszerzenie dotychczasowej wiedzy i umiejętności ( $N=31 ; 16,9 \%)$, satysfakcję osobistą ( $N=27 ; 15,3 \%)$ i samodzielność zawodową ( $\mathrm{N}=22 ; 12,4 \%)$. Tylko 4 osoby $(2,3 \%)$ podały, że uzyskały awans. Niektórzy podkreślali również nowe możliwości zawodowe pielęgniarek ( $N=22 ; 11,9 \%$ ), lepszą jakość opieki paliatywno-hospicyjnej ( $N=19 ; 10,3 \%)$ oraz większą dostępność opieki paliatywno-hospicyjnej ( $N=10 ; 5,4 \%)$. Nieliczni specjaliści zwracali uwagę na możliwość lepszego kontraktowania świadczeń przez Narodowy Fundusz Zdrowia ( $N=2 ; 1,09 \%)$ oraz otwierania nowych oddziałów opieki paliatywnej ze względu na dostępność specjalistycznej kadry $(\mathrm{N}=1 ; 0,54 \%)$.

Interesujący jest również fakt, że pomimo uzyskania wyższych kwalifikacji zawodowych i tytułu specjalisty niektórzy badani wyrazili pewne obawy w związku z wykonywaniem swojej pracy - obawę przed sprawieniem bólu choremu podczas wykonywania czynności pielęgniarskich ( $N=70 ; 38 \%$ ), przed wypaleniem zawodowym związanym z brakiem widocznych efektów podjętych działań i wyczerpaniem emocjonalnym ( $\mathrm{N}=64 ; 34,8 \%)$ obawę przed niewłaściwą, raniącą wypowiedzią do chorego lub rodziny ( $N=61 ; 33,2 \%$ ), przed oglądaniem ludzkiego cierpienia ( $N=37 ; 20,1 \%)$ oraz w związku z niemożnością porozumienia się z chorym ( $N=34 ; 18,5 \%)$. Zaniepokojenie związane z wypaleniem zawodowym, brakiem widocznych efek- tów podjętych działań i wyczerpaniem emocjonalnym silniej niż pozostali uczestnicy badań wyrażały pielęgniarki z dłuższym stażem pracy w opiece paliatywno-hospicyjnej powyżej 20 lat, w wieku 40-50 lat i więcej, z wykształceniem średnim, pracujące w hospicjum domowym lub w oddziale opieki paliatywnej. Pozostałe obawy częściej były sygnalizowane przez specjalistki z wykształceniem wyższym zawodowym, w wieku poniżej 40. roku życia, pracujące w hospicjum stacjonarnym.

\section{Dyskusja}

W obszarze opieki paliatywno-hospicyjnej dążenie pielęgniarek do podnoszenia kwalifikacji podyktowane jest specyfiką zapotrzebowania odbiorców świadczeń na całościową i zintegrowaną opiekę pielęgniarską, zorientowaną na rozwiązywanie złożonych problemów osób nieuleczalnie chorych oraz ich rodzin. Działanie takie w ujęciu systemowym stanowi wyjście naprzeciw rosnącym oczekiwaniom pacjentów wobec fachowości profesjonalistów medycznych oraz poziomu usług. Zaangażowanie pracowników w sprawy związane z zapewnieniem i podnoszeniem jakości własnych świadczeń sprzyja wzrostowi zadowolenia z pracy, ale także dążeniom i aspiracjom, którymi stają się na przykład wzrost wynagrodzenia czy awans [4]. Na ogólną satysfakcję z pracy składa się wartość pracy w perspektywie odczuć pracownika, takich jak: odpowiedzialność, satysfakcja z efektów pracy i osiągnięć [5].

Uczestnicy badań wyraźnie wskazali, że specjalizacja była dla nich istotna w aspekcie doskonalenia wiedzy i umiejętności, zdobywania nowych doświadczeń, kompetencji i uprawnień, również osiągania większej samodzielności i w związku z tym stanowiła asumpt do wyróżnienia oraz poszanowania. Można przyjąć, że poczucie wspomnianych osiągnięć ma szerszy wymiar i trwalsze efekty niż formalna nagroda $[5,6]$.

Specjalistyczne kompetencje powinny znaleźć swój wyraz w gwarancjach uprawnień zawodowych, w tym związanych z możliwością podejmowania samodzielnych decyzji i działań w profesjonalnym pielęgnowaniu [7]. Tu interesująco przedstawia się kwestia korzystania z prawnie uregulowanych uprawnień. Z badań wynika, że najwięcej specjalistek korzysta z uprawnienia do doboru sposobów opatrywania ran i odleżyn (którego świadczenie wymaga kursu specjalistycznego, a nie specjalizacji). Z grupy pozostałych świadczeń przypisanych specjalistce w dziedzinie pielęgniarstwa opieki paliatywnej do tych najczęściej wykonywanych należą: ocena i monitorowanie bólu, innych objawów u przewlekle chorego oraz ocena wydolności fizycznej chorego, a także modyfikacja dawki leczniczej leku przeciwbólowego i leków stosowanych w celu łagodzenia innych dokuczliwych objawów. 
Warto zauważyć, że samodzielność specjalistek objętych badaniem własnym jest w praktyce stosunkowo niewielka i ograniczona do sytuacji koniecznych, zwłaszcza w opiece domowej. Świadczenia samodzielne realizowane są przeważnie przez osoby lepiej wykształcone i z dłuższym stażem pracy. Ci specjaliści w większości nie wykonują jednak badania fizykalnego i nie kierują na badania diagnostyczne, tłumacząc to m.in. brakiem wystarczającej wiedzy lub pewności siebie, realizacją tych świadczeń przez lekarzy albo brakiem zainteresowania pracodawcy co do sformalizowania takich działań w miejscu pracy.

Pewna część badanych wskazała na potrzebę pogłębienia treści kształcenia ujętych w programie specjalizacji o zagadnienia dotyczące psychoonkologii, prowadzenia rozmowy z umierającym i jego rodziną. Potrzeby te korespondują z obawami wyrażanymi w badanej grupie przed niewłaściwą, raniącą wypowiedzią do chorego lub rodziny, oglądaniem ludzkiego cierpienia, niemożnością porozumienia się z chorym oraz przed wypaleniem zawodowym związanym z brakiem widocznych efektów podjętych działań i wyczerpaniem emocjonalnym.

W świetle badania prowadzonego przez Renn-Żurek i wsp. w Łodzi praca z umierającym pacjentem stwarza pielęgniarkom wiele problemów psychologicznych, niezależnie od ich wieku i formy sprawowanej opieki paliatywnej. Trudne emocje wynikają m.in. ze współdoświadczania cierpienia chorych i obcowania ze śmiercią, a także niewspółmiernych do realiów oczekiwań rodzin [8]. W badaniu Dobrowolskiej i wsp., dotyczącym zapotrzebowania na kształcenie podyplomowe z zakresu opieki nad pacjentem umierającym, w którym uczestniczyli pracownicy medyczni z lubelskiego szpitala, również podkreślano potrzebę doskonalenia umiejętności w zakresie współpracy z rodziną, komunikacji z umierającym oraz radzenia sobie $w$ z własnymi emocjami w obliczu śmierci pacjenta [9]. W badaniu własnym sytuacja ta była dla ankietowanych szczególnie trudna, gdy dotyczyła opieki paliatywno-hospicyjnej nad nieuleczalnie chorymi dziećmi. Warto podkreślić, że nowy program szkolenia specjalizacyjnego w dziedzinie pielęgniarstwa opieki paliatywnej z 2015 r. poszerza specjalizację o powyższe zagadnienia, zarówno w części teoretycznej, jak i praktycznej. Należy zatem wyrazić nadzieję, że będzie on realizowany w formie umożliwiającej pogłębienie umiejętności radzenia sobie w powyższych sytuacjach.

\section{Wnioski}

1. Większość badanych specjalistów w dziedzinie pielęgniarstwa opieki paliatywnej podkre- śla przydatność szkolenia specjalizacyjnego, szczególnie w aspekcie poprawy jakości własnej pracy z chorym, fachowości, biegłości i wysokiej sprawności w działaniu.

2. Tylko niektórzy specjaliści korzystają z uprawnień do samodzielnego wykonywania świadczeń. Są to głównie świadczenia związane z udziałem w obserwacji i terapii bólu przewlekłego oraz oceną jakości życia chorego. Specjaliści przeważnie nie kierują na badania diagnostyczne. Największą samodzielnością zawodową cechują się pielęgniarki w hospicjum domowym i stacjonarnym.

3. Dla większości badanych podniesienie kwalifikacji skutkuje satysfakcją osobistą i uznaniem społecznym. Ukończenie specjalizacji to przede wszystkim osiągnięcie prestiżu, rzadko awansu lub podwyżki wynagrodzenia.

4. Ukończona specjalizacja w dziedzinie pielęgniarstwa opieki paliatywnej stwarza nowe możliwości zawodowe, ale wysokie kwalifikacje tej kadry nie są w pełni wykorzystywane w zakładach pracy.

\section{Piśmiennictwo}

1. Rozporządzenie Ministra Zdrowia z dnia 29 października 2013 r. w sprawie świadczeń gwarantowanych z zakresu opieki paliatywnej i hospicyjnej. Dz.U. z 2013 r. poz. 1347.

2. Ustawa z dnia 15 lipca 2011 r. o zawodach pielęgniarki i położnej. Dz.U. z 2011 r. Nr 174, poz. 1039 z późn. zm.

3. Rozporządzenie Ministra Zdrowia $z$ dnia 7 listopada 2007 r. w sprawie rodzaju i zakresu świadczeń zapobiegawczych, diagnostycznych, leczniczych i rehabilitacyjnych udzielanych przez pielęgniarkę albo położną samodzielnie bez zlecenia lekarskiego. Dz.U. z 2007 r. Nr 210, poz. 1540.

4. Opolski K, Dykowska G, Możdżonek M. Zarządzanie przez jakość w usługach zdrowotnych. Warszawa: Wyd. CeDeWu; 2005.

5. Armstrong M. Zarządzanie ludźmi. Praktyczny przewodnik dla menedżerów liniowych. Poznań: Dom Wydawniczy Rebis; 2007.

6. Chmielewska E. Wpływ czynników motywujących na kształcenie podyplomowe pielęgniarek w Wojewódzkim Szpitalu Specjalistycznym w Legnicy. Zeszyty Naukowe Państwowej Wyższej Szkoły Zawodowej im. Witelona. 2012; 8: 19-32.

7. Bielawska J. Kompetencje zawodowe pielęgniarki. Zeszyty Naukowe Państwowej Wyższej Szkoły Zawodowej im. Witelona. 2012; 8: 5-15.

8. Renn-Żurek A, Jamrozik P, Piontkowska M. Problemy psychologiczne pielęgniarek pracujących w oddziałach medycyny paliatywnej oraz w hospicjum domowym. J Publ Health Nurs Med Rescue. 2014; 4: 51-58.

9. Dobrowolska B, Putowski M, Wrońska I, Kozak D, Cuber M. Zapotrzebowanie pielęgniarek i lekarzy na kształcenie podyplomowe z zakresu opieki nad pacjentem umierającym. Probl Piel. 2008; 16(1,2): 48-53. 
Artykuł przyjęty do redakcji: 27.11.2015

Artykuł przyjęty do publikacj: 15.07.2016

Źródło finansowania: dotacja na badania statutowe w Zakładzie Pielęgniarstwa Klinicznego Wydziału Nauki o Zdrowiu Warszawskiego Uniwersytetu Medycznego.

Konflikt interesów: Autorzy deklarują brak konfliktu interesów.

\section{Nazwa kongresu, na którym ogłoszono pracę:}

Innowacyjność w kształceniu, praktyce pielęgniarskiej i badaniach naukowych. 90-lecie powstania Uniwersyteckiej Szkoły Pielęgniarek i Opiekunek Zdrowia w Krakowie. 2015 r.

Podziękowania: Autorzy wrażają serdeczne podziękowanie za okazaną pomoc w przeprowadzeniu badań Pani mgr Izabeli
Kaptacz, konsultantowi krajowemu w dziedzinie pielęgniarstwa opieki paliatywnej, oraz Pani mgr Małgorzacie Kulas z Ostrowa Mazowieckiego.

\section{Adres do korespondencji:}

Ewa Kądalska

ul. Spartańska 1

02-637 Warszawa

tel.: 228360972

e-mail: ekadalska@wp.pl

Klinika i Poliklinika Geriatrii

Narodowy Instytut Geriatrii, Reumatologii i Rehabilitacji

im. prof. dr hab. med. Eleonory Reicher w Warszawie 